\title{
MODEL SKIN DEFECTS IN RATS FOR THE COMPOSITE SKIN GRAFT EVALUATION
}

\author{
P. BRYCHTA, D. *HORKÝ, D. HAVRANOVÁ, Z. JANEČEK, J. ADLER \\ Burn Centre and Tissue Bank, University Hospital, Brno \\ *Department of Histology and Embryology, Faculty of Medicine, Masaryk University, Brno
}

Received September 2, 1996

Accepted February 10, 1997

\begin{abstract}
Brychta P., D. Horký, D. Havranová, Z. Janecek, J. Adler: Model Skin Defects in Rats for the Composite Skin Graft Evaluation. Acta vet. Brno, 1997, 66:23-26.

An animal model (rat) was used for the study of the wound healing process. Full-thickness round skin defects, $3 \mathrm{~cm}$ in diameter, placed on the dorsal side of the body were made down to muscle fascia. Plastic rings were used to prevent wound contraction and spontaneous epithelialization from the wound edges.

In the first step allodermis was prepared using trypsin, and applied into the wound bed. Cultured epidermal autografts were prepared in vitro using modified Rheinwald-Green method, and in the second step applied on the taken allodermis. In this way composite skin grafts consisting of allodermis and cultured epidermal autografts were constructed. The semipermeable dressing was changed three-times a week.

The healing process was monitored using both the appearance and light microscopic evaluation. In the experimental group of 10 animals uniform uncomplicated healing of these composite skin grafts occurred.

After 3 months, the composite skin grafts acquired a form very similar to intact skin missing only the appendages (hair and glands). In the microscopic view only rather flat rete ridges under the dermo-epidermal junction made the difference between the graft and intact skin.
\end{abstract}

Model skin defects, cultured epidermal autografts, allocorium, composite skin grafts

The substitution of the skin damaged in its full thickness due to injury, especially burn, has not been resolved quite satisfactorily. Keratinocytes cultured in vitro represent a hopeful perspective for solving this problem (Rhein wald and Green 1975; Green et al. 1979). However, it seems that a mere substitution of the epidermis is not quite satisfactory because a good-quality substitution also requires a corial component (Compton et al. 1989; Schiozer et al. 1994).

The aim of the present study was therefore to approach this problem by recombining allogeneic corium and autologous cultured keratinocytes used for covering of a fullthickness skin defect. A rat experimental model was employed.

\section{Materials and Methods}

Ten white laboratory non-inbred female rats, 6 months old, $300-400 \mathrm{~g}$ body mass, were used for the experiment (four intact rats were used as the control group).

Surgical interventions were performed in general anaesthesia with $0.2 \mathrm{ml}$ Rometar $2 \%+0.8 \mathrm{ml}$ Narkoman $5 \% . \mathrm{kg}^{-1}$ body mass.

A skin sample for keratinocyte cultivation was taken from the right inguinum of a rat. Hair was removed from the skin, the skin was disinfected with "Spitaderm TM“", a sample in its full-thickness, $2 \times 1 \mathrm{~cm}$, was excised in a sterile way and transported into laboratory in Dulbecco - Minimal Essential Medium (D-MEM) with antibiotics. The skin defect was simply sutured.

After removal from the transport medium, the skin sample was placed into $0.2 \%$ solution of trypsin and incubated at $4{ }^{\circ} \mathrm{C}$ for 24 hours. Then it was washed with Phosphate Buffered Saline (PBS), and keratinocytes were loosened mechanically from the corium in a small amount of the medium. Epithelial cells were 
centrifuged for $10 \mathrm{~min}$. at $1000 \mathrm{rpm}$, and resuspended in $5 \mathrm{ml}$ of medium for keratinocytes. A line of $3 \mathrm{~T} 3$ mouse fibroblasts was used as the feeder cells. They were inoculated on polystyrene Petri dishes, diameter $5 \times 5 \mathrm{~cm}$. When the growth occurred at about $80 \%$ of the culture surface, mitotic activity was inhibited with Mitomycine $(5 \mu \mathrm{g} / 1 \mathrm{ml}$ medium). After washing off, 3 drops of keratinocyte suspension were inoculated on each dish, and the volume of the medium was supplemented to $5 \mathrm{ml}$ per dish. The Petri dishes were placed into an incubator with a moist atmosphere, $5 \% \mathrm{CO}_{2}$, and constant temperature of $37{ }^{\circ} \mathrm{C}$. Twenty four hours after keratinocyte seeding, the medium was exchanged, and Epidermal Growth Factor (EGF) and Choleratoxin were added. The medium with factors was exchanged once in 2 days. Keratinocytes formed a multilayer within 2-3 weeks. In this phase, they were applied onto the experimental defect, made in the same animal. Inguinal suture was healed.

A full-thickness skin sample, $3 \mathrm{~cm}$ in diameter, was taken from the dorsal side after removal of hair and skin disinfection. The skin was incubated in $0.2 \%$ solution of trypsin at $4{ }^{\circ} \mathrm{C}$ for $24 \mathrm{~h}$. Afterwards, the epidermis was scraped off mechanically, and the remaining corium was stored in sterile water at $4{ }^{\circ} \mathrm{C}$ for 14 days so that remaining cells lyzed in a hypotonic medium. Before the final application to another animal this allocorium was perforated (Plate I., Fig. 1).

The circular skin defect, $3 \mathrm{~cm}$ in diameter, made into the muscle fascia on the dorsal side of an experimental rat can be seen in Fig. 2. The corium of the skin for further set of experiments was prepared as mentioned above.

To prevent contraction of the skin defect and its epithelialization from the wound edges, plastic rings, $3 \mathrm{~cm}$ in diameter, $0.5 \mathrm{~cm}$ high, were used (Plate II.. Fig. 3). The ring was sutured to the wound edges. An opening served to fasten the dressing that could be exchanged in a painless way without anaesthesia. The material of the ring was tested using Minimal Essential Medium /MEM/ elution test for cytotoxicity on HeLa cell line and was found nontoxic when compared with a positive control sample.

\section{Application of the corium and keratinocytes}

Immediately after the excision, the allocorium adjusted beforehand was inserted onto the wound demarcated by the ring (Fig. 4), covered with gauze and compressive dressing. After $72 \mathrm{~h}$, the covering was removed, and cultured epidermal autografts separated mechanically from the bottom of a culture dish were placed on the corium. The wound was covered with a vaseline gauze and a compressive dressing moistened with saline solution. The vaseline gauze was exchanged for the first time on the 7th day after the keratinocyte application. The same method was used for a comparative experiment in which only the allocorium was applied.

The healing process was checked both macroscopically and microscopically (skin biopsies). Fourteen days later, the rings were removed, and the wound was left without dressings.

\section{Results}

The capillary ingrowth and vascularization of the allocorium was first observed on the 3rd day after the application of the corium - white colour turned pink and cultured epidermal autografts were applied.

Vaseline gauze was removed on the 7th day after the corium application. Islets of epithelium (the implanted and growing keratinocytes) were found on the surface of the corium. The corium has nearly taken. The secretion of the wound was serous, without any sings of a purulent process. On palpation, the graft was soft, smooth and firm.

On the 19th day after the application, the islets of keratinocytes formed a confluent layer (Plate III., Fig. 5). At that time, the first sample was taken for histological examination (Fig. 6). After removal of the ring, the graft became gradually connected with the adjacent skin, and the wound healed completely without a more pronounced contraction in contrast to findings in the control group (four animals), to which the corium alone (without subsequent application of cultured epidermal allografts) was applied. In these animals, after removal of the rings the defects healed by epithelialization from edges and contracted conspicuously to about $1 / 4$ of the original size.

Between days 25 -30 after application (Plate IV., Figs. 7, 8), the second histological sample was taken for examination and after healing of the wound, on the 101st day after transplantation the third one (Plate V., Fig. 9). 


\section{Discussion}

The results of the present study indicate that application of allocorium followed by that of cultured keratinocytes 72 hours later produced functional composite skin grafts in our experiments on rats. Interestingly, in spite of using the allodermis no rejection occurred, and the graft inhealed uneventfully. Good tolerability was most likely caused by the low immunogenity of the corium which was treated to reduce the number of cells with osmotic lysis. High reparation activity of rats played its role in satisfactory healing as well.

Macroscopically, the defect appeared to be healed on about day 20 in majority of the experimental animals. For technical reasons, the ring could not be left in situ more than 20 days because of its spontaneous expulsion. As there was no more barrier present between the graft and adjacent skin, it was not possible to prevent migration of keratinocytes from the edges towards the centre of the graft. At that time, cultured keratinocytes formed with allodermis a sufficiently resistant substitutional covering to prevent the wound healing per secundam and its scar contraction.

Due to good tolerability of the composite graft, the results can be compared to the conventional dermoepidermal autograft. Thus for possible broader use in clinical practice, the problem of donor shortage could be resolved using this method. The allodermis could be obtained from cadaver donors, and keratinocytes themselves prepared by means of in vitro culture.

Literature gives a few reports on the keratinocyte grafting in rats that were used for preparing our research project (Hafeman et al. 1994; Fabre and Cullen 1989; B oyce et al. 1991). Further information source are the publications concerning composite grafts (e.g. Ben-Basat et al. 1992; Wainwright 1993).

\section{Conclusion}

In model skin defect in rats a functional composite skin graft can be created from the allodermis and cultured autologous keratinocytes. This graft takes without problems, and forms a skin substitution comparable with the dermoepidermal graft (Plate V., Fig. 10).

\section{Modelové kožní defekty u krys pro hodnocení kompozitních kožních štěpů}

Ke studiu hojení rány byl použit zvírrecí model. Na hřbetech krys byly vytvořeny okrouhlé defekty v celé tlouštce kůže až ke svalové fascii o průměru $3 \mathrm{~cm}$. Plastikové kroužky byly použity, aby zabránily kontrakci rány a její spontánní epitelizaci z okrajủ.

$\mathrm{V}$ první fázi byla připravena trypsinací allogenní dermis a aplikována na spodinu rány. In vitro byly připraveny kultivované epidermální autotransplantáty modifikovanou Rheinwald-Greenovou metodou a ve druhé fázi byly aplikovány na přihojenou allogenní dermis. Tímto způsobem byly zkonstruovány kompozitní kožní štěpy, sestávající z allogenní dermis a kultivovaných epidermálních autotransplantátů. Semipermeabilní ranný kryt byl vyměňován $3 \times$ týdně.

Proces hojení byl monitorován jednak makroskopicky a jednak pomocí světelné mikroskopie.

Po třech měsících měly kompozitní štěpy vzhled velmi podobný intaktní kủži, postrádaly pouze adnexa (chlupy, žlázy). V mikroskopickém obraze spočíval rozdíl mezi štěpem a intaktní kủží pouze $v$ poněkud mělčích papilách dermoepidermální junkce. $V$ našem desetičlenném souboru experimentálních zvîrat došlo jednotně $\mathrm{k}$ nekomplikovanému zhojení těchto kompozitních štěpů. 


\section{Acknowledgements}

This work was supported by the Czech Ministry of Health grant No. 3725 B.

\section{References}

BEN-BASAT, H., ELDAD, A., CHAOUAT, M., LIVOFF, R., NEEMAN, Z., WEXLER, R. 1992: Structural and functional evaluation of modifications in the composite skin graft: Cryopreserved dermis and cultured keratinocytes. Plast. Reconstr. 89:510-520

BOYCE, S. T., FOREMAN, T. J., ENGLISH, K. B., STAINER, N., COOPER, M.L., SAKABU, S., HANSBROUGH, J. F. 1991: Skin wound closure in athymic mice with cultured human cells, biopolymers and growth factors. Surgery 110:866-876

COMPTON, C., GILl, J. M., BRADFORD, D. A., REGAUER, S., GALLICO, G.G., CONNOR, E. 1989: Skin regenerated from cultured epithelial autografts on full-thickness burn wounds from 6 days to 5 years after grafting. Lab. Invest.60:600

FABRE, J. W., CULLEN P. R. 1989: Rejection of cultured keratinocyte allografts in the rat. Transplantation 48:306-315

GREEN, H., KEHINDE. O., THOMAS, J. 1979: Growth of cultured human epidermal cells into multiple epithelia suitable for grafting. Proc. Natl. Acad. Sci. USA 76:5665-5668

HAFEMAN, B., HETTICH, R., ENSSLEN, S., KOWOL, B., ZÜHLKE, A., EBERT, R., KÖNIX, M., KIKRPATRICK, C. J. 1994: Treatment of skin defects using suspensions of in vitro cultured keratinocytes. Burns 20:168-182

RHEINWALD, J. G., GREEN, H. 1975: Serial cultivation of strains of human epidermal keratinocytes:the formation of colonies from single cells. Cell 6:331-344

SCHIOZER, W. A., HARTINGER, A., HENCKEL VON DONNERSMARCK, G., MÜHLBAUER, W. 1994: Composite grafts of autogenic cultured epidermis and glycerol-preserved allogeneic dermis for definitive coverage of full-thickness burn wound. Case report. Burns 20:503-507

WAINWRIGHT, D. 1993: Case study: Acellular allograft dermal matrix. Potential as a permanent skin replacement in full-thickness burns. Life Cell Rep.

Address for correspondence:

MUDr. Pavel Brychta, CSc.

Burn and Reconstructive Surgery Centre

University Hospital

Jihlavská 20

63900 Brno

Czech Republic

Phone 420543215250

Fax 420543215250 
Plate I.-V.

Brychta P. et al.: Model Skin Defects... pp. 23-26.

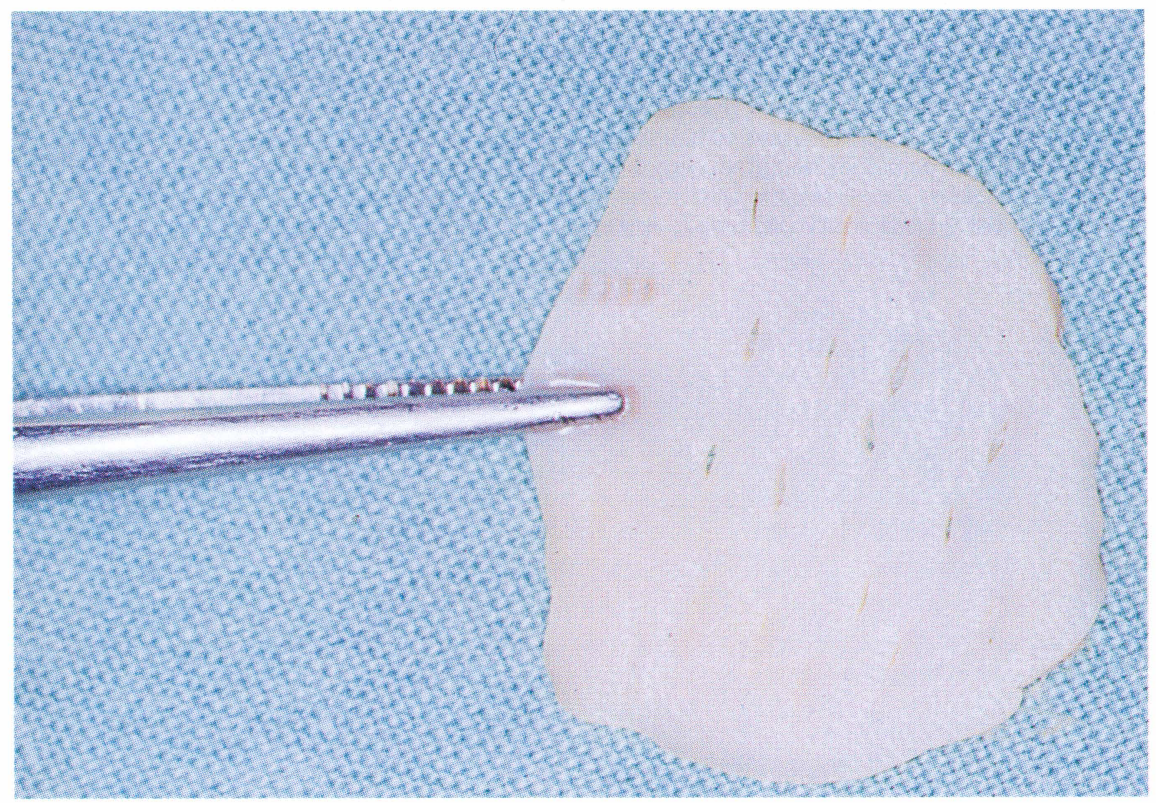

Fig. 1. Deepidermalized, acellular dermis, perforated immediately before the implantation into the skin defect.

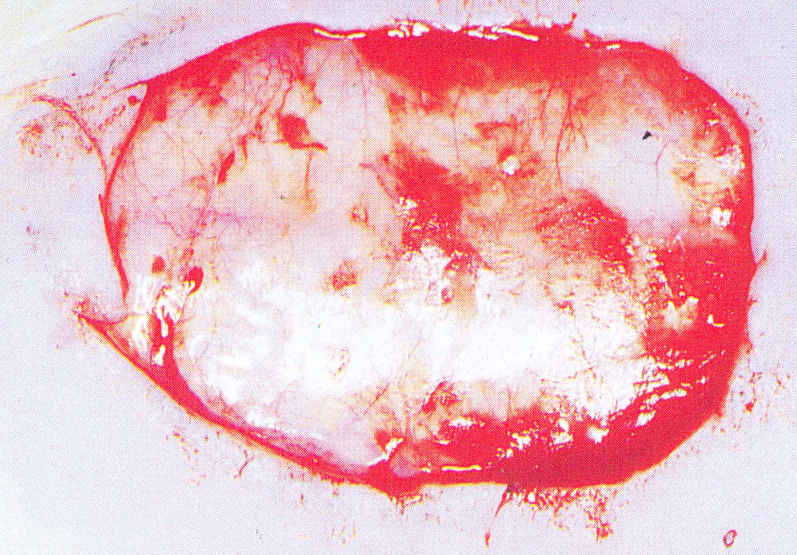

Fig. 2. Artificially created full-thickness skin defect, $3 \mathrm{~cm}$ in diameter on the back of the rat. 


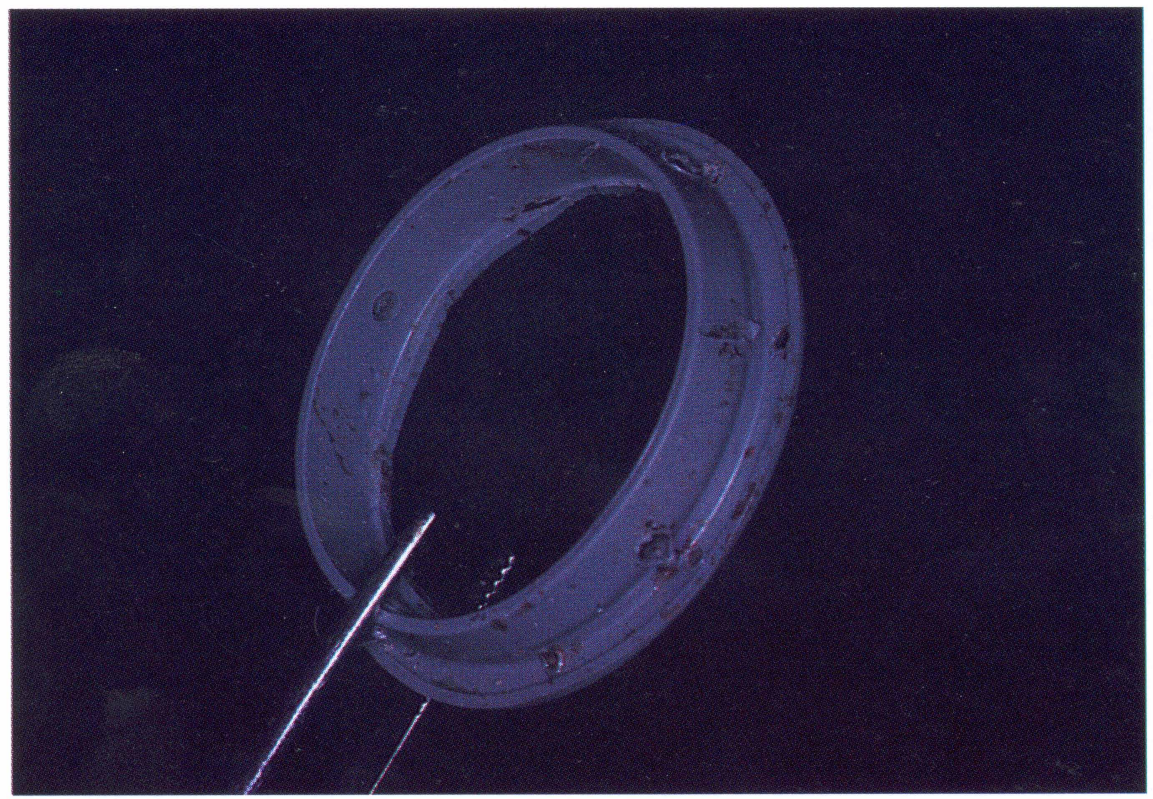

Fig. 3. Plastic ring, $3 \mathrm{~cm}$ in diameter prepared for the implantation into the skin defect.

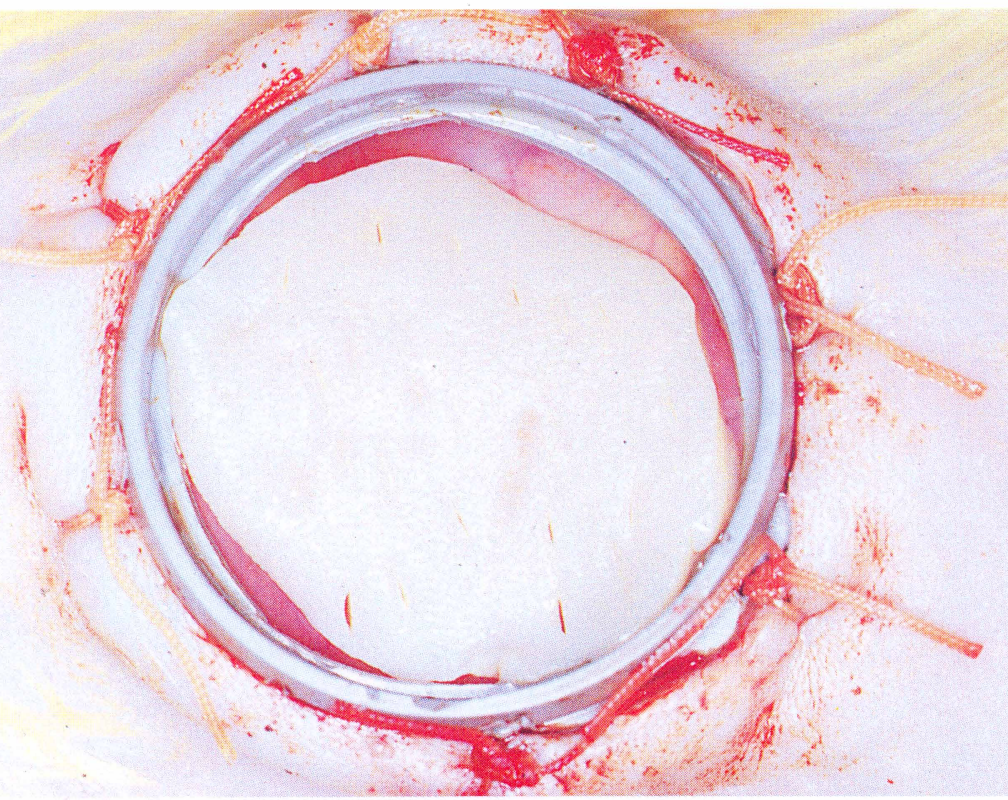

Fig. 4. Plastic ring sutured in the skin defect, allocorium immediately after application onto the muscle fascia. 
Plate III.

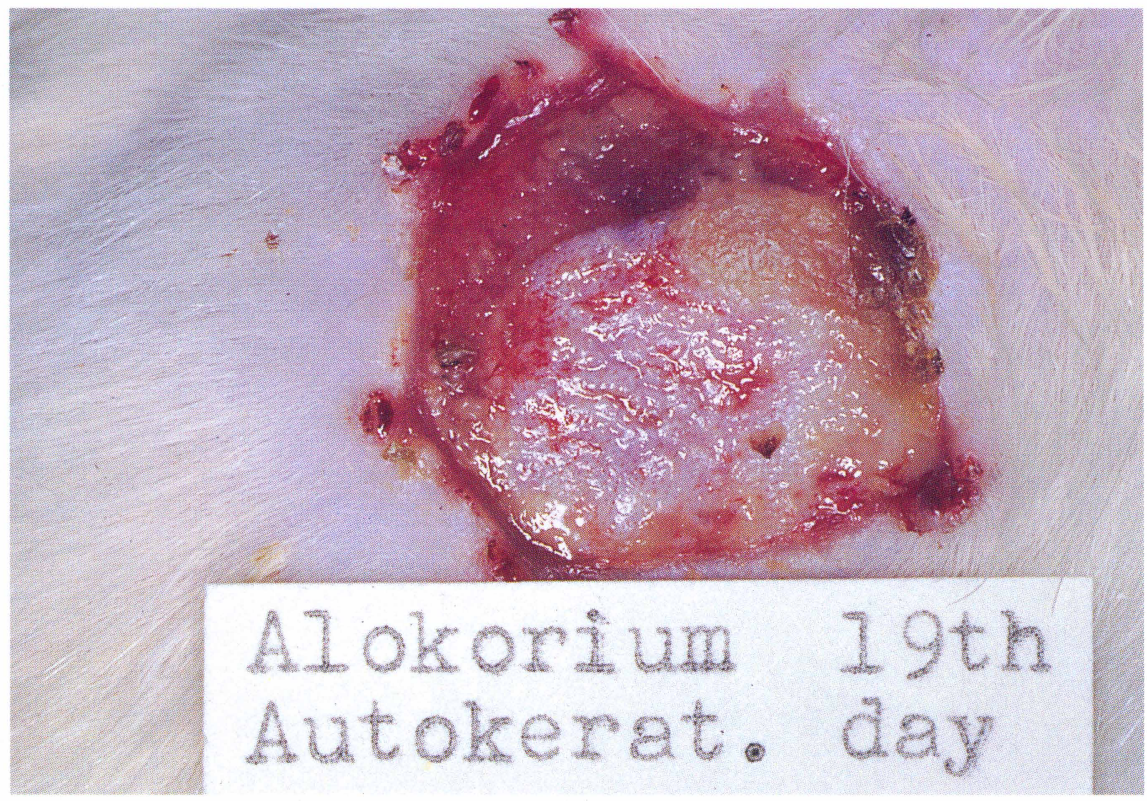

Fig. 5. Composite graft 19 days after application of the allocorium, the islets of keratinizing cultured autologous keratinocytes are clearly seen. Situation immediately after removal of the plastic ring.

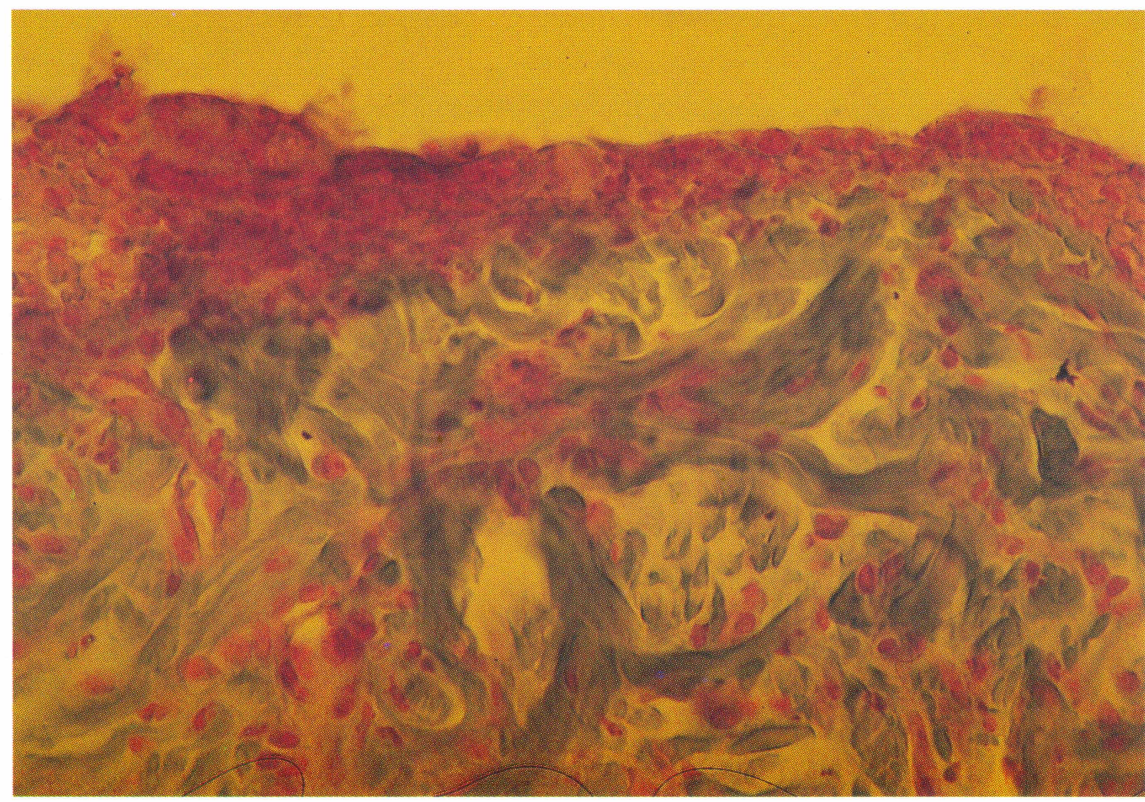

Fig. 6. Microscopic picture of the composite graft 19 days after application. The epidermal part has the form of multilayer of autologous keratinocytes /minimum 3 layers/ without any structure like epidermis. Basal membrane is not present. The structure of allogeneic corium is hardly distinguisable from normal skin. Magnification x 250. 


\section{Alokorium 26th \\ Autokerat. day}

Fig. 7. The same defect 26 days after grafting. Confluent epidermal sheet on top of the allogeneic dermis.

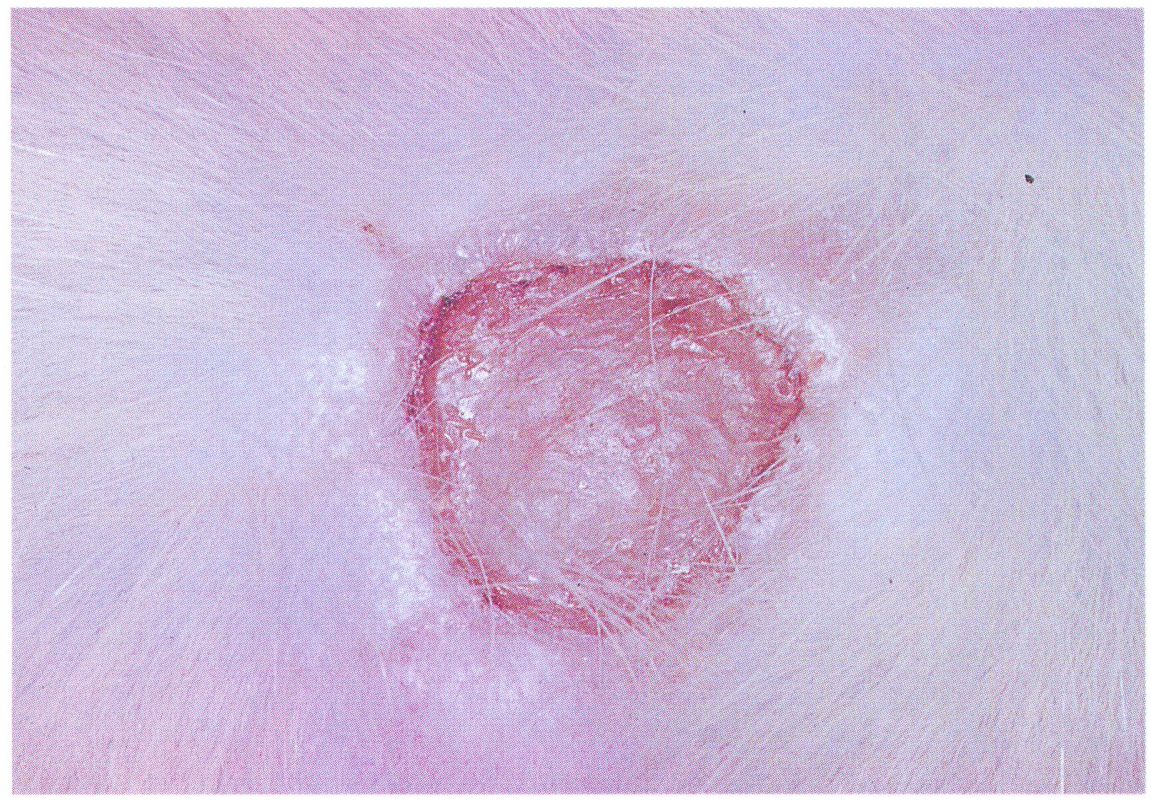

Fig. 8. On day 30 is composite graft nearly healed. 
Plate V.

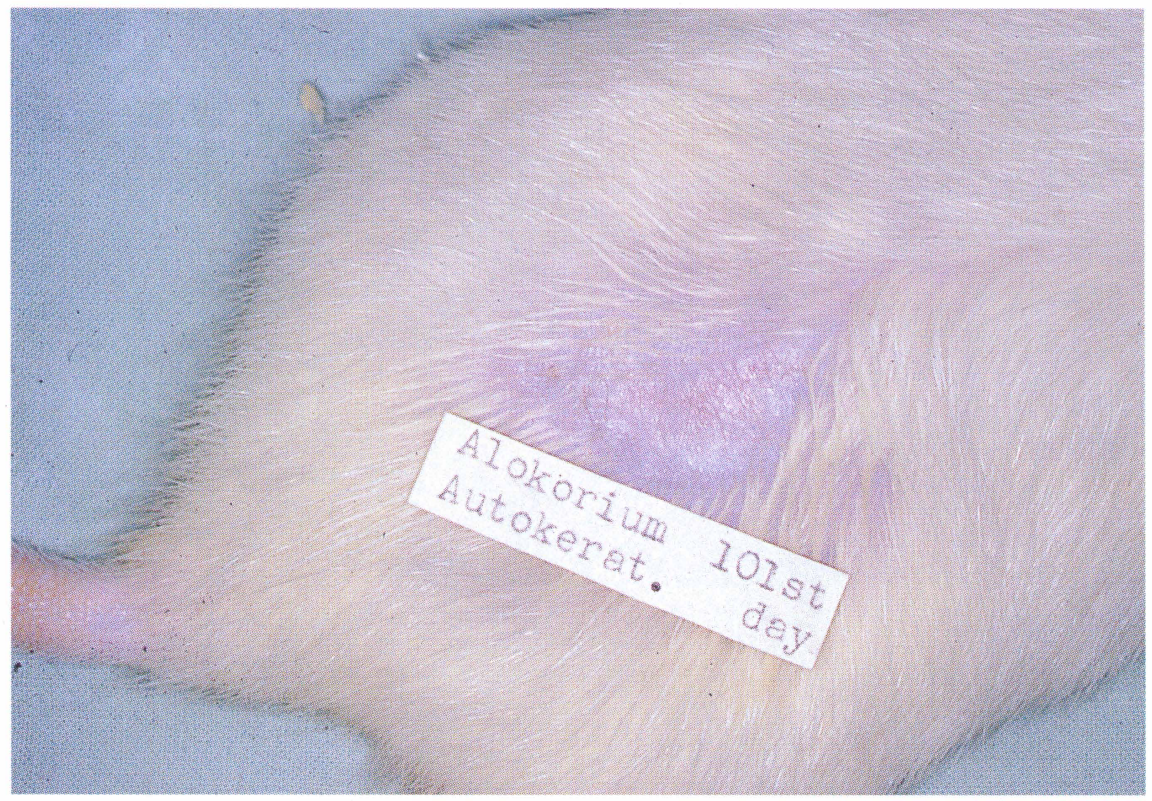

Fig. 9. Final gross appearance of the composite graft 101 days after its application. Absence of hair.

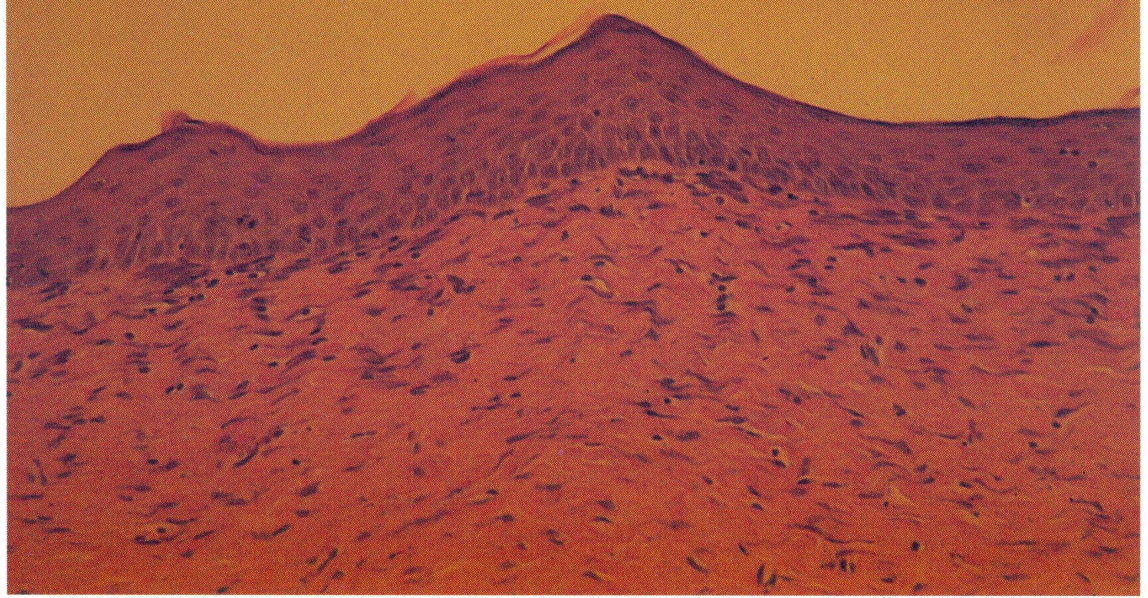

Fig. 10. Microscopic picture of the composite graft 101 days after application. Fully differentiated epidermis with keratinization, flat rete ridges, no inflammation in the dermis. Magnification x 250 . 